University of Nebraska - Lincoln

DigitalCommons@University of Nebraska - Lincoln

\title{
Mercury and methylmercury concentrations and loads in the Cache Creek watershed, California
}

Joseph L. Domagalski

U.S. Geological Survey, joed@usgs.gov

Charles N. Alpers

U.S. Geological Survey, cnalpers@usgs.gov

Darell G. Slotton

University of California - Davis

Thomas H. Suchanek

US Fish and Wildlife Service

Shaun M. Ayers

University of California - Davis

Follow this and additional works at: https://digitalcommons.unl.edu/usgsstaffpub

Part of the Earth Sciences Commons

Domagalski, Joseph L.; Alpers, Charles N.; Slotton, Darell G.; Suchanek, Thomas H.; and Ayers, Shaun M., "Mercury and methylmercury concentrations and loads in the Cache Creek watershed, California" (2004). USGS Staff -- Published Research. 488.

https://digitalcommons.unl.edu/usgsstaffpub/488

This Article is brought to you for free and open access by the US Geological Survey at DigitalCommons@University of Nebraska - Lincoln. It has been accepted for inclusion in USGS Staff -- Published Research by an authorized administrator of DigitalCommons@University of Nebraska - Lincoln. 


\title{
Mercury and methylmercury concentrations and loads in the Cache Creek watershed, California
}

\author{
Joseph L. Domagalskia,*, Charles N. Alpers ${ }^{\mathrm{a}}$, Darell G. Slotton ${ }^{\mathrm{b}}$, Thomas H. Suchanek ${ }^{\mathrm{c}}$, \\ Shaun M. Ayers ${ }^{\mathrm{b}}$ \\ ${ }^{a}$ US Geological Survey, Placer Hall, 6000 J Street, Sacramento, CA 95819-6129, USA \\ ${ }^{\mathrm{b}}$ Department of Environmental Science and Policy, University of California, One Shields Avenue, Davis, CA 95616, USA \\ ${ }^{\mathrm{c}}$ US Fish and Wildlife Service, 2800 Cottage Way, Sacramento, CA 95825, USA
}

Received 16 September 2003; accepted 13 January 2004

\begin{abstract}
Concentrations and loads of total mercury and methylmercury were measured in streams draining abandoned mercury mines and in the proximity of geothermal discharge in the Cache Creek watershed of California during a 17-month period from January 2000 through May 2001. Rainfall and runoff were lower than long-term averages during the study period. The greatest loading of mercury and methylmercury from upstream sources to downstream receiving waters, such as San Francisco Bay, generally occurred during or after winter rainfall events. During the study period, loads of mercury and methylmercury from geothermal sources tended to be greater than those from abandoned mining areas, a pattern attributable to the lack of large precipitation events capable of mobilizing significant amounts of either mercury-laden sediment or dissolved mercury and methylmercury from mine waste. Streambed sediments of Cache Creek are a significant source of mercury and methylmercury to downstream receiving bodies of water. Much of the mercury in these sediments is the result of deposition over the last 100-150 years by either storm-water runoff, from abandoned mines, or continuous discharges from geothermal areas. Several geochemical constituents were useful as natural tracers for mining and geothermal areas, including the aqueous concentrations of boron, chloride, lithium and sulfate, and the stable isotopes of hydrogen and oxygen in water. Stable isotopes of water in areas draining geothermal discharges showed a distinct trend toward enrichment of ${ }^{18} \mathrm{O}$ compared with meteoric waters, whereas much of the runoff from abandoned mines indicated a stable isotopic pattern more consistent with local meteoric water.
\end{abstract}

(c) 2004 Elsevier B.V. All rights reserved.

Keywords: Mercury; Methylmercury; Abandoned mines; Water quality

\section{Introduction}

The Cache Creek watershed (Fig. 1) is an important source of total inorganic mercury to

\footnotetext{
*Corresponding author. Tel.: + 1-916-278-3077.

E-mail address: joed@usgs.gov (J.L. Domagalski).
}

downstream areas including the San Francisco Bay, and the region known as the Delta of the Sacramento and San Joaquin rivers (Domagalski, 1998, 2001; Domagalski and Dileanis, 2000; Foe and Croyle, 1999). Although the Cache Creek drainage basin covers only approximately $4 \%$ of the area drained by the Sacramento River (Fig. 1), the 

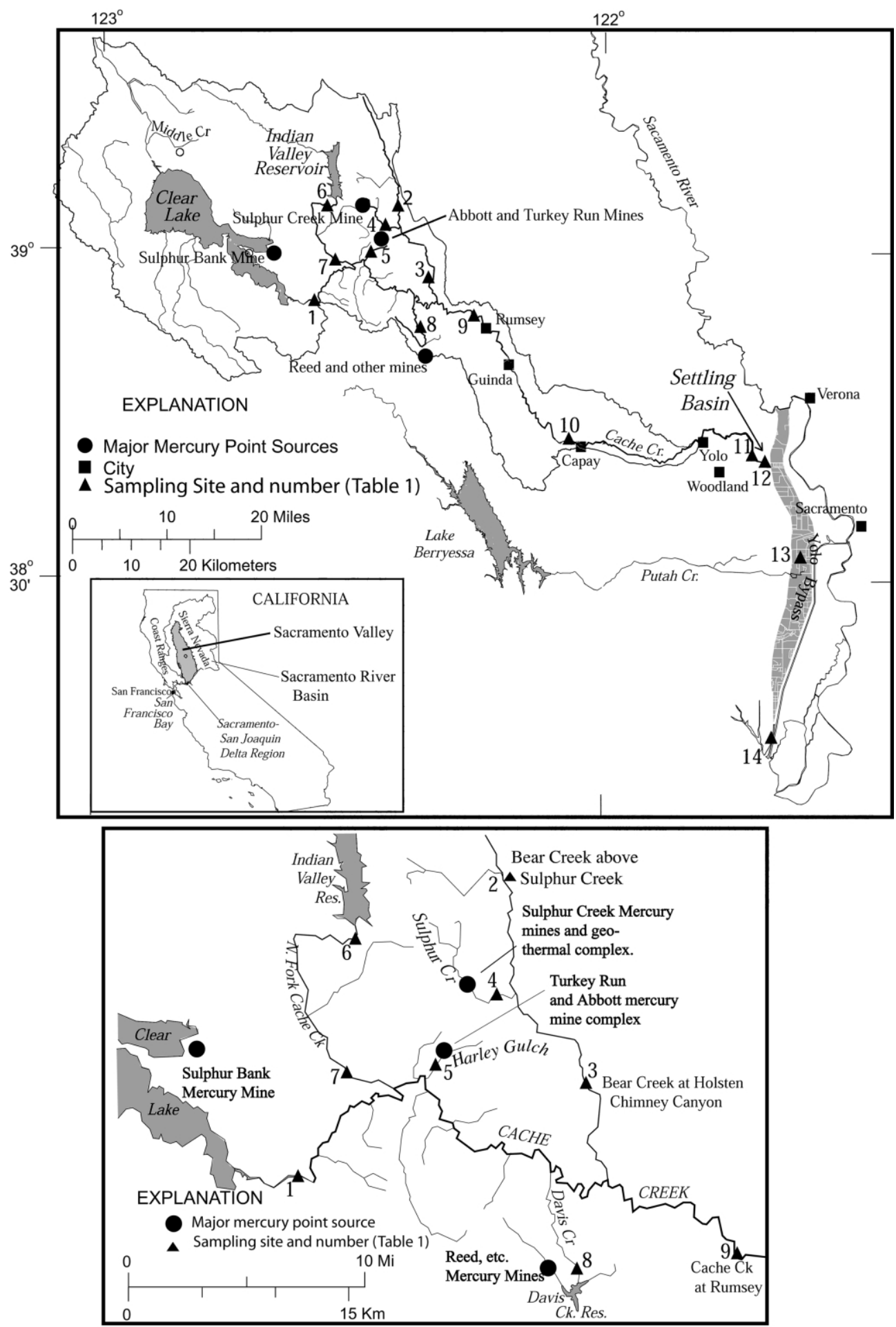

Fig. 1. Map of study area and location of sampling sites. 
amount of total mercury transported downstream can be as high as $50 \%$ of the total annual load of the Sacramento River (Foe and Croyle, 1999). Sources of mercury within the Cache Creek watershed include natural geothermal springs, abandoned and inactive mercury mines, and mercury prospects (Fig. 1). Sulphur Creek (Fig. 1) has several active geothermal springs within its drainage.

Mercury was mined at several locations in the Cache Creek basin. The mercury-sulfide mineral, cinnabar $(\mathrm{HgS})$, occurs in deposits near the Clear Lake area (Fig. 1) and other locations within the Cache and Putah creek drainages. The mercury deposits in the region near Clear Lake are hydrothermal in origin, of Cenozoic Age, and are the most northern part of a group of similar deposits associated with volcanism and the migration of a transform fault system within the central portion of the California Coast Ranges (Rytuba, 1996). Production of mercury in California was especially high during the period after 1850 following the discovery of placer gold deposits in the California Sierra Nevada. Peak production of mercury occurred in 1877 when the various mines of the California Coast Ranges produced approximately 2776 metric tons of elemental mercury that were primarily used in gold recovery operations (Bradley, 1918). Residues from the abandoned mercury mines remain a source of total mercury to Cache Creek and downstream receiving bodies of water (Foe and Croyle, 1999; Domagalski, 1998). Mining wastes can enter streams primarily through runoff associated with rain, and the highest observed concentrations and loads of total mercury in Cache Creek have followed rainfall events (Domagalski, 1998, 2001). Mercury from geothermal sources enters the creeks year-round.

The mercury transported from the Cache Creek basin to receiving waters may pose a human health problem if that mercury enters the aquatic food web and eventually bioaccumulates as methylmercury in fish to levels above health guidelines. Currently, the potential for the mercury of the Cache Creek basin to change to the methylated form, either within the Cache Creek basin or when transported to a downstream receiving body of water such as the Delta, is largely unknown. Most of the mercury transported through Cache Creek is presumably in the form of cinnabar as a suspended solid. The cinnabar must dissolve to liberate aqueous $\mathrm{Hg}$ (II) before the mercury can be transformed to methylmercury. No studies have yet documented the fraction of mercury present as methylmercury at various locations within the Cache Creek watershed.

The present study was designed to determine local sources of total mercury and methylmercury within the Cache Creek watershed and to determine the mass loadings from those sources. It was hypothesized that the greatest loadings would occur from previously mined regions where little or no removal of mine wastes have occurred, and that loads from geothermal sources would be stable, but minor compared to those of mine wastes. Furthermore, it was hypothesized that stable isotopes of hydrogen and oxygen in water, or other geochemical tracers such as born and lithium could be used to help relate mercury concentrations or loads in water to source areas. The study determined the concentrations and loadings during a time frame from January 2000 through May 2001 and assessed the seasonal effects on concentrations and loadings. The study is part of a larger investigation on mercury and its effects both within the Cache Creek watershed and downstream in the Delta of the Sacramento and San Joaquin rivers. The larger investigation is examining mercury bioaccumulation, the potential of mine remediation within the Cache Creek watershed to reduce mercury loads, and mercury bioaccumulation-related issues associated with ecosystem restoration projects within the Delta of the Sacramento and San Joaquin rivers.

\section{Study area and methods}

The Cache Creek Basin occupies approximately $3000 \mathrm{~km}^{2}$ in Northern California (Fig. 1). The area upstream of Rumsey is characterized by the low hills of the California Coast Ranges whereas the area downstream of Rumsey flattens out to become part of the Sacramento Valley. Land cover in the upstream portion of the basin is mainly forest and grazing land with minor amounts of orchards and cropland. The amount of land used 
Table 1

Site names and numbers from Fig. 1

\begin{tabular}{ll}
\hline Site number & Site name \\
\hline 1 & Cache Creek near Lower Lake \\
2 & Bear Creek above Sulphur Creek \\
3 & Bear Creek above Holsten Chimney Canyon \\
4 & Sulphur Creek at Wilbur Springs \\
5 & Harley Gulch near Wilbur Springs \\
6 & North Fork Cache Creek near Clearlake Oaks \\
7 & North Fork Cache Creek at Highway 20 \\
8 & Davis Creek Reservoir at dam, near Knoxville \\
9 & Cache Creek at Rumsey \\
10 & Cache Creek near Highway 505 \\
11 & Cache Creek into Settling Basin \\
12 & Cache Creek out of Settling Basin \\
13 & Yolo Bypass at Interstate 80 near West Sacramento \\
14 & Lower Yolo Bypass \\
\hline
\end{tabular}

for crops increases downstream of Rumsey. Former mine sites represent a relatively small amount of the total land cover. Cache Creek has its origin as outflow from Clear Lake. The largest tributary to Cache Creek, the North Fork of Cache Creek, has its origin in the northern part of the basin and includes the Indian Valley Reservoir. Another major tributary to Cache Creek is Bear Creek. The Bear Creek watershed does not have a reservoir. Both Clear Lake and Indian Valley Reservoir are managed to supply irrigation water to farmers in the lower parts of the Cache Creek basin. In fact, summertime flows in Cache Creek and the North Fork of Cache Creek are entirely managed for irrigation usage, and essentially no water reaches the Sacramento River during the summer and fall months (Domagalski et al., 2000a). Fall and early wintertime flows tend to be low because releases from Clear Lake and Indian Valley Reservoir are very low. Higher flows occur in winter in response to seasonal rainfall. In addition, the level of Clear Lake or Indian Valley Reservoir is occasionally lowered during the winter months for flood protection. The rainy season occurs from November through March, although each year is variable with respect to timing and amount of rainfall. The water from Cache Creek that leaves the basin enters a seasonal flood-control channel of the Sacramento River system known as the Yolo Bypass (Fig. 1), which is designed to reduce the potential of flood- ing in adjacent areas and cities. The Yolo Bypass discharges very little water during the dry season.

There are numerous smaller tributaries to Cache Creek; some draining abandoned mining sites and geothermal areas. One of these smaller tributaries is Harley Gulch (Fig. 1), which drains an abandoned mercury mine complex (the Turkey Run and Abbott mines). Another is Davis Creek (Fig. 1), which drains the Reed Mine. The Sulphur Creek (Fig. 1) drainage includes both natural sources of mercury from geothermal springs and some mine wastes, including both mercury and gold mines. Sulphur Creek drains into Bear Creek, a tributary to Cache Creek above Rumsey.

Sampling sites (Fig. 1 and Table 1) were selected to assess representative locations of potential sources of mercury within the Cache Creek watershed. Stream sites immediately downstream of the dams on both Clear Lake and Indian Valley Reservoir were sampled to determine mercury and methylmercury concentrations from either the lake or reservoir. Sampling sites were situated on small tributaries or other water bodies near mercury mines or natural mercury sources. There were two sites on Bear Creek which included an upper site, Bear Creek above Sulphur Creek (Fig. 1, site 2); and a lower site, Bear Creek above Holsten Chimney Canyon (Fig. 1, site 3). There was one site on Sulphur Creek (Fig. 1, site 4), one on Harley Gulch (Fig. 1, site 5), and one on Davis Creek 
Reservoir at its spillway (Fig. 1, site 8). The upper Bear Creek site is situated above the mercury mines and geothermal springs. Additional sites situated on Cache Creek included a site at Rumsey (Fig. 1, site 9), which is centrally located in the Cache Creek Basin, and sites just upstream of the point where Cache Creek discharges to the Yolo Bypass (Fig. 1, sites 10, 11 and 12); these latter two sites bracket the Cache Creek Settling Basin, which is designed to trap sediment transported out of the Cache Creek watershed. Finally, two sites were situated in the Yolo Bypass (Fig. 1, sites 13 and 14): one in the central portion of the Yolo Bypass (Yolo Bypass at Interstate 80 near West Sacramento) and the second site (Lower Yolo Bypass) just upstream of where the Yolo Bypass discharges into the Delta region.

In addition to the sites listed in Table 1, two mine-site areas in the Cache Creek watershed were sampled in more detail by a separate team from the University of California, Davis (UCD). The location of several sampling sites in both the Abbott-Turkey Run mine-site area and the Sulphur Creek mine-site area are described in detail by Suchanek et al. (2002).

The US Geological Survey (USGS) sampled some sites, including the Yolo Bypass sites and the site immediately downstream of the dam on Indian Valley Reservoir, and the UCD team sampled some sites, such as the Bear Creek above Sulphur Creek and Cache Creek near Highway 505. Other sites were sampled by both the USGS and UCD.

Water samples collected by the USGS were width- and depth-integrated and were collected with a sampler designed for the collection of isokinetic samples (Shelton, 1994; Edwards and Glysson, 1988; Ward and Hair, 1990; US Geological Survey, 1999). The water samples were collected in 3-1 Teflon bottles that had been cleaned for the purpose of collecting water samples for mercury and trace metals. The Teflon bottles were originally cleaned by immersion in $10 \%$ hydrochloric acid at $65^{\circ} \mathrm{C}$ for a period of 3 days. After thorough rinsing with ultra-clean water, the bottles were tightly capped and double-wrapped in plastic for transport to a field site. After collection of a water sample, the bottles were rinsed with ultra- clean water and then field-cleaned with a dilute detergent, followed by thorough rinsing with ultraclean water, a rinse with $5 \%$ hydrochloric acid, and a final series of rinses with ultra-clean water. One set of sampling bottles was only used for geothermal or mercury mine sites expected to have higher mercury concentrations; while another set was only used for downstream sites on the larger creeks and rivers expected to have lower mercury concentrations. After collection, the water samples were composited in an 8-1 Teflon-lined stainlesssteel churn. The cleaning procedure for a churn involved washing with dilute detergent followed by thorough rinsing with ultra-clean water, a thorough internal rinse with 5\% hydrochloric acid, and a final series of rinses with ultra-clean water. Similar to the procedure with the 3-1 Teflon sampling bottles, one churn was used only for mining or geothermal sites, and a second churn was used only for the sites on the larger creeks and rivers.

Water samples were taken from the churn for various analyses of whole-water (unfiltered) samples such as suspended sediment concentration, mercury and methylmercury in unfiltered water, trace elements in unfiltered water, and measurement of $\mathrm{pH}$ and specific conductance. Water samples were then collected for analyses of filtered samples with a $0.45 \mu \mathrm{m}$, high-capacity capsule filter. The filtration order for samples was total mercury, methylmercury, other trace metals, and finally alkalinity.

Water samples collected by UCD differed from those taken by the USGS in that the UCD samples were grab samples collected in that part of the river or stream judged to have the greatest discharge. The UCD group did not filter samples in the field, but rather transported the samples by overnight courier or ground transport to the corresponding laboratory, where samples were immediately filtered and preserved. Samples taken for mercury and methylmercury were collected in 11 , pre-washed glass bottles. Samples for trace metals, alkalinity and stable isotopes were taken in 4-1 polyethylene bottles that were cleaned with the same procedure described above for the Teflonlined churns.

Water samples collected by the USGS for the measurement of total mercury in water were ana- 
lyzed according to the method of Roth (1994), which utilizes cold vapor atomic fluorescence spectrometry. Water samples collected by UCD were also analyzed with a cold vapor atomic fluorescence methodology, and complete details are given in Puckett and van Buuren (2000). The method was based on that of the US Environmental Protection Agency (US EPA, 1996). Methylmercury in water was measured by a similar method following distillation and ethylation of aqueous samples (Puckett and van Buuren, 2000). Selected trace elements in water were analyzed by inductively coupled plasma mass spectroscopy (Alpers et al., 2000).

Full details of laboratory and field quality assurance requirements are given by Puckett and van Buuren (2000). Field-level quality assurance consisted of the collection of blanks and replicates. Seven field blanks were collected for total mercury in unfiltered and filtered water during the three sampling events completed by the USGS. The concentrations of total mercury in unfiltered water blanks ranged from less than detection $(0.5 \mathrm{ng} / \mathrm{l})$ to $1.2 \mathrm{ng} / 1$. The median level was $0.6 \mathrm{ng} / 1$. The median was estimated by setting the concentrations of non-detected values to one half the detection limit. The concentrations of total mercury in filtered blank samples ranged from less than detection $(0.5 \mathrm{ng} / 1)$ to $1.2 \mathrm{ng} / 1$. The median value was less than the detection limit. Therefore, bias caused by contamination does not affect the data set, as the levels of mercury measured in environmental samples are much higher than those measured in blank samples. The range in measured concentrations of total mercury in environmental samples was less than the detection limit to $3070 \mathrm{ng} / \mathrm{l}$, and $98 \%$ of all measured concentrations exceeded a concentration of $1 \mathrm{ng} / \mathrm{l}$.

Six field blanks were collected for methylmercury in unfiltered and filtered water during the three sampling events completed by the USGS. Most of the measurements were less than the detection limit of $0.02 \mathrm{ng} / \mathrm{l}$. Two samples of methylmercury in unfiltered water had concentrations just slightly above the detection limit, and the highest concentration was $0.03 \mathrm{ng} / \mathrm{l}$. Therefore, bias caused by contamination does not affect the measurements of methylmercury.
All samples collected for total mercury in unfiltered and filtered water by the USGS were taken in duplicate, and each of the duplicate samples was analyzed in triplicate. The median relative percent difference (RPD) for the values of total mercury in unfiltered water samples was $3.5 \%$, whereas that for filtered water samples was $6.4 \%$. The higher RPD for the filtered water samples may be attributed to the relatively lower concentrations of total mercury in filtered water. A total of six replicates were collected by the USGS for methylmercury analysis. The median RPD for methylmercury in whole water samples was $8.5 \%$, whereas that in filtered water was $4.5 \%$.

The UCD sampling team also collected field blanks and replicates. The median concentration of total mercury in unfiltered water blanks was $0.32 \mathrm{ng} / \mathrm{l}$. The median concentration of methyl mercury in unfiltered water blanks was less than the detection limit of $0.02 \mathrm{ng} / \mathrm{l}$. The median concentration for the field blanks taken by the UCD team and filtered at the Batelle Laboratory was $0.072 \mathrm{ng} / 1$ for filtered total mercury, and below the detection limit of $0.024 \mathrm{ng} / 1$ for filtered methylmercury. The median RPD of total mercury in unfiltered water for the UCD sampling team was $8.6 \%$ and that for methylmercury in unfiltered water was $13.3 \%$. The RPD for methylmercury in filtered water for the samples collected by UCD was $7.5 \%$ and that for methylmercury was $20.1 \%$.

A separate laboratory quality assurance program was used for the analysis of oxygen and hydrogen isotope ratios in unfiltered water samples. Isotopic analyses of oxygen and hydrogen atoms in water were recorded as ratios relative to Standard Mean Ocean Water (SMOW-V, O’Neil, 1986). Isotope ratios of oxygen $\left({ }^{18} \mathrm{O} /{ }^{16} \mathrm{O}\right.$, expressed as $\left.\delta^{18} \mathrm{O}\right)$ and hydrogen $\left({ }^{2} \mathrm{H} /{ }^{1} \mathrm{H}\right.$, expressed as $\left.\delta \mathrm{D}\right)$ in water were measured with a light stable isotope ratio mass spectrometer. Oxygen isotope measurements were done on $\mathrm{CO}_{2}$ after equilibration with the water at $25{ }^{\circ} \mathrm{C}$. Hydrogen isotope measurements were done on $\mathrm{H}_{2}$ after reduction of the water with zinc with a platinum catalyst (Bigeleisen et al., 1952; Kendall and Coplen, 1985). The laboratory uses a calibration procedure with three unique standards, with each standard analyzed in duplicate with each analytical run. In all cases, the laboratory 
was able to calibrate the instruments according to the known values of isotope ratios in the standards. The laboratory also completed 18 duplicate measurements of $\delta^{18} \mathrm{O}$ and 16 duplicate measurements of $\delta \mathrm{D}$ during the time when the environmental samples from this study were analyzed. The average differences in the replicates for $\delta^{18} \mathrm{O}$ were 0.03 per mil and that for $\delta \mathrm{D}$ were 0.4 per mil. Another quality assurance check was made by including 13 samples of de-ionized (DI) water as blind replicates. The S.D. for 13 measurements of the DI water were 0.07 per mil for $\delta^{18} \mathrm{O}$ and 0.8 per mil for $\delta \mathrm{D}$.

\section{Results and discussion}

The general strategy for determination of mass loads was two-fold: (1) to collect samples of storm water run-off because of the higher river flows and the greater potential for transport of mercury and methylmercury; and (2) to collect samples at pre-planned intervals during the dry season. The rainy season and peak river flows generally occur between November and March, with little or no rainfall and low river discharge during the remainder of the year. Rainfall was below normal during the period of this study, and discharge from Cache Creek was relatively low compared to historical records. The discharge for water year 2000 (1 October 1999 through 30 September 2000) for the Cache Creek at Yolo was only 55\% of the longterm average based on data from 1903 to 2000 (Anderson et al., 2001). Discharge during water year 2001 was even less than that of water year 2000. Therefore, the results of this study reflect low-flow conditions in these streams and rivers.

Concentrations of total mercury in whole and filtered water samples are shown in Fig. 2 for the larger stream sites, and in Fig. 3 for the smaller stream sites. As expected, the mining and geothermal sites had the highest concentrations, and most of the total mercury was associated with suspended sediment, especially for the sites on Cache Creek downstream of Bear Creek. The fraction of total mercury associated with particles increased downstream from the mining sites. The median ratio for the filtered to unfiltered total mercury for the Cache Creek at Rumsey site was 0.13 , while that for the inflow to the Cache Creek Settling Basin was 0.1, and that for the Yolo Bypass was 0.12. In contrast, the median ratio of filtered to unfiltered total mercury for the Sulphur Creek at Wilbur Springs site was 0.26 , while the median ratio for the Harley Gulch site was 0.45 , and that for the Bear Creek above Holsten Chimney Canyon site was 0.43 . Therefore, soluble mercury enters the streams near the mine or geothermal sites, but then either precipitates or becomes associated with particles as the water from those tributaries and its associated load of mercury, discharge into Cache Creek. Concentrations of total mercury were lower at most of the downstream locations than at the mining and geothermal sites, because of their distance from these sources and because of dilution from the two largest sources of water, Clear Lake and Indian Valley Reservoir, or precipitation of the dissolved mercury.

Concentrations of methylmercury in whole water and filtered water samples for selected sites are shown in Figs. 4 and 5. The highest concentrations were measured in water from Sulphur Creek at Wilbur Springs, Bear Creek above Holsten Chimney Canyon, and Harley Gulch near Wilbur Springs. Concentrations of methylmercury were generally higher in whole water samples than in filtered samples. The ratio of methylmercury in the filtered water samples to that for total methylmercury in unfiltered water was higher than the corresponding ratio for total mercury. The ratio of methylmercury in filtered water samples to whole water samples ranged from approximately 0.1 to greater than 1 , and the median ratio ranged from 0.29 to 0.78 for all sites. These ratios for methylmercury were considerably more variable than the corresponding ones for total mercury, at all sites.

Tables of instantaneous daily loads of total mercury for selected sites are given for data from February and March 2000 (Table 2), and February 2001 (Table 3). The periods of time presented in Tables 2 and 3 correspond to when samples of storm water runoff were collected at the sites. For the year 2000 sampling, the total instantaneous mercury loads were relatively low near the mining and geothermal sites relative to the downstream sites because of the lower discharges from the mining and geothermal sites. Loads of total mer- 

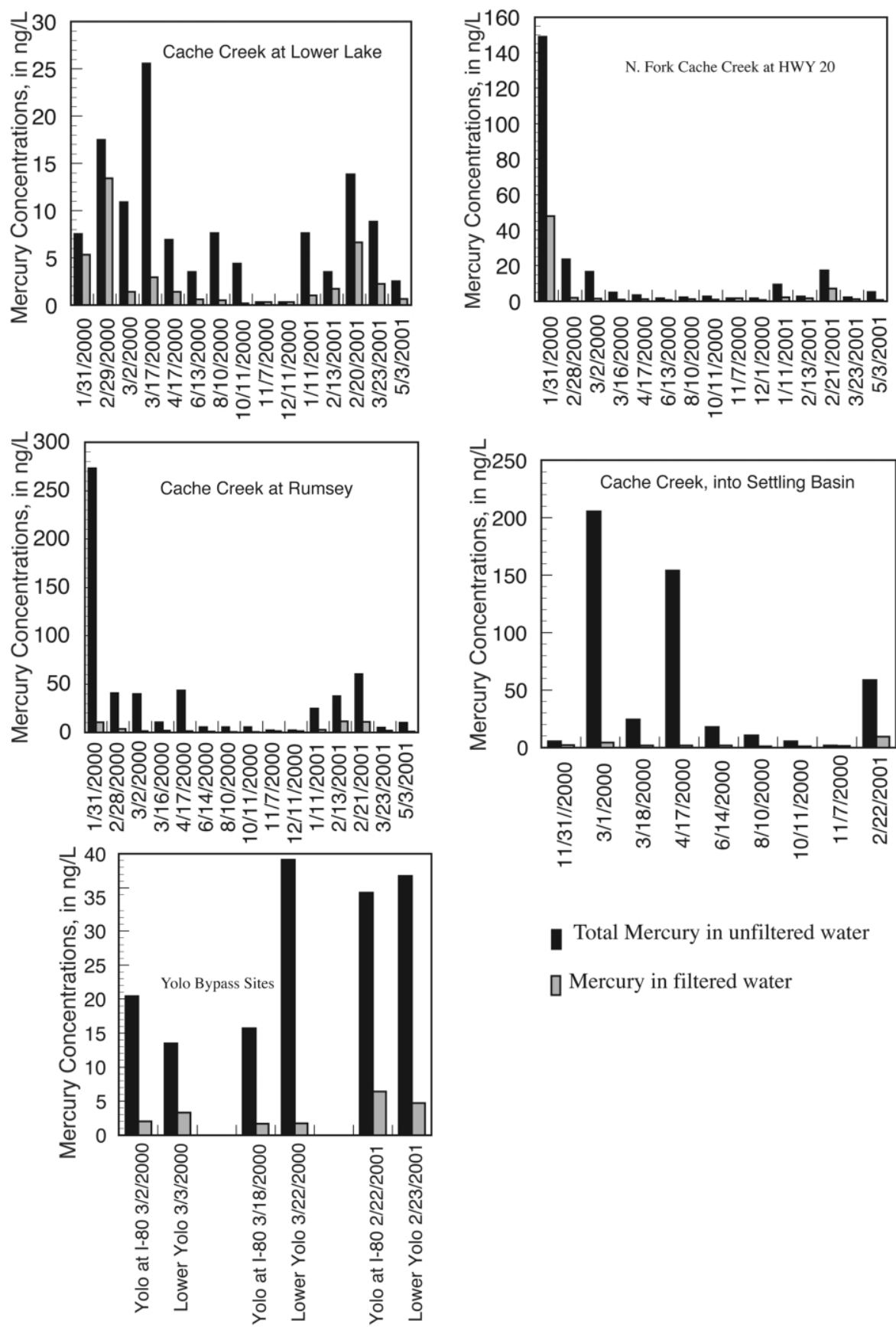

Total Mercury in unfiltered water Mercury in filtered water

Fig. 2. Mercury concentrations at large river sites. 

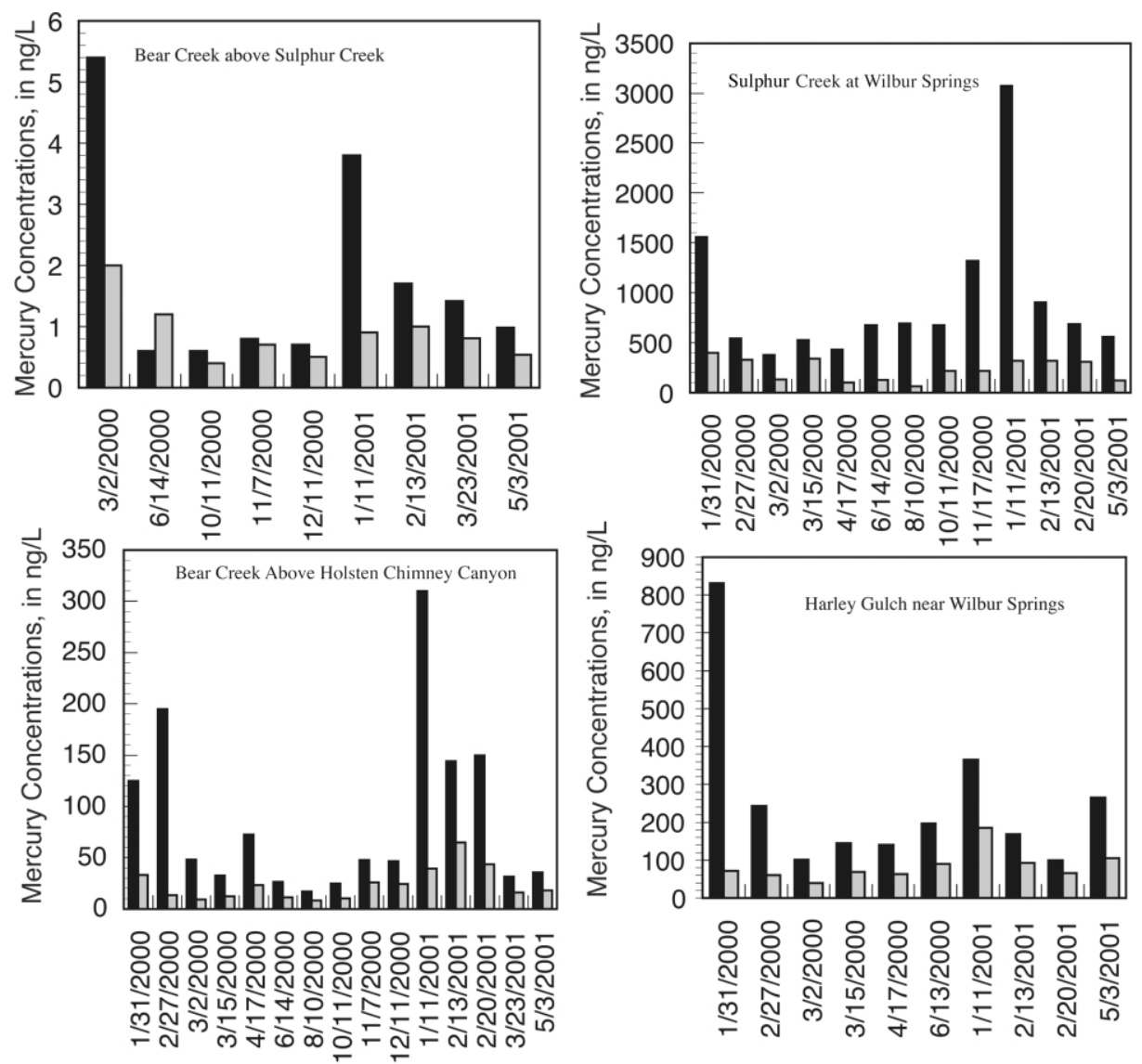

Total Mercury in unfiltered water
Mercury in filtered water

Fig. 3. Mercury concentrations at small stream sites.

cury increased downstream during the FebruaryMarch 2000 storm, and the downstream loads exceeded the sum of the loads from the mining and geothermal sites. For the samples collected during February 2000, part of the downstream increase could be attributed to hydrological or water management factors. Midway during the period of time that samples were being collected, on 28 February 2000, water began to be released from the Clear Lake dam to lower water levels of Clear Lake to reduce the risk of flooding to lakeside property. The discharge of Cache Creek at Rumsey and at downstream sites during sampling, for example, contained both storm-water runoff and released water from Clear Lake, where- as discharge at the time of sampling at the mining and geothermal sites, as well as the sites on the North Fork of Cache Creek, contained only stormwater runoff. Therefore, the higher loads at the Cache Creek at Rumsey, and downstream at the settling basin can be logically attributed primarily to re-suspension of previously deposited mercury in the bottom sediments as a result of higher flows from the released water. The load of total mercury at the sites furthest downstream, i.e. the Yolo Bypass at Interstate 80 near West Sacramento and the Lower Yolo Bypass resulted from combined flows from Cache Creek and the Sacramento River. No attempt was made, nor are data available, to discriminate between these sources. 

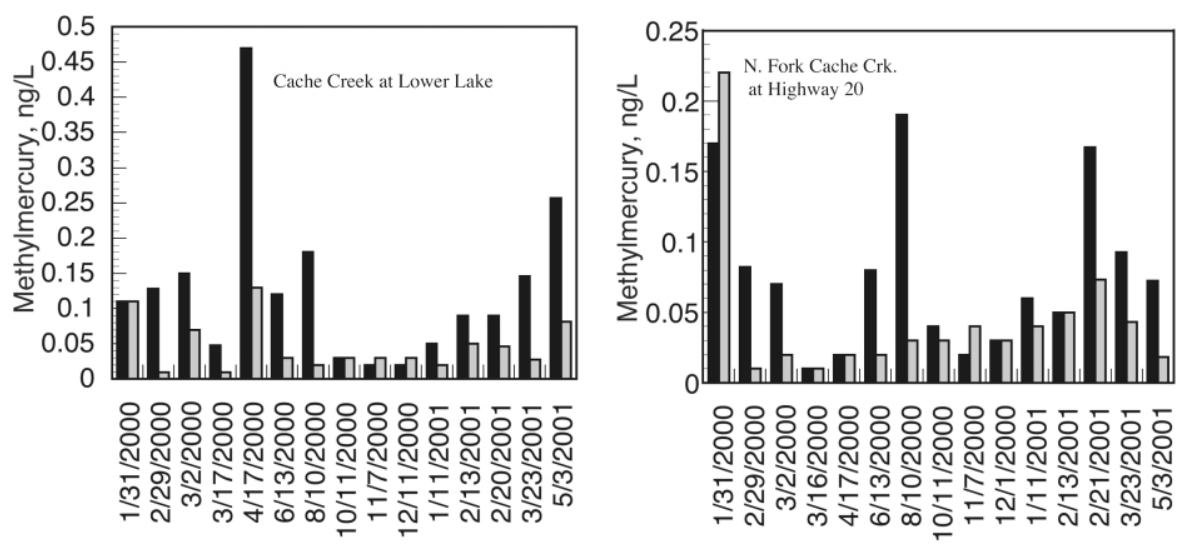

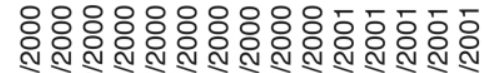

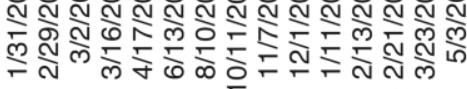
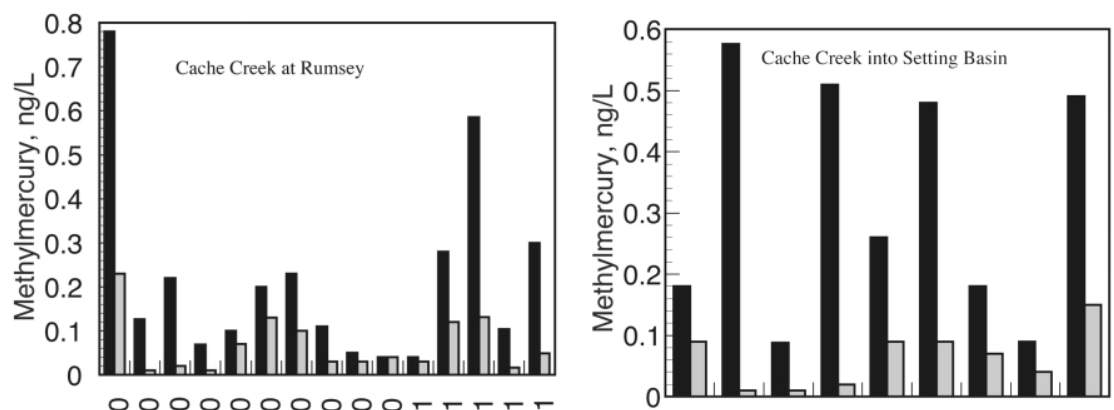

ㅇㅇㅇㅇㅇㅇㅇㅇㅇㅇㅇㅇㅇㅎㅎㅎㅎㅎㅎㅎ웅 然 m)
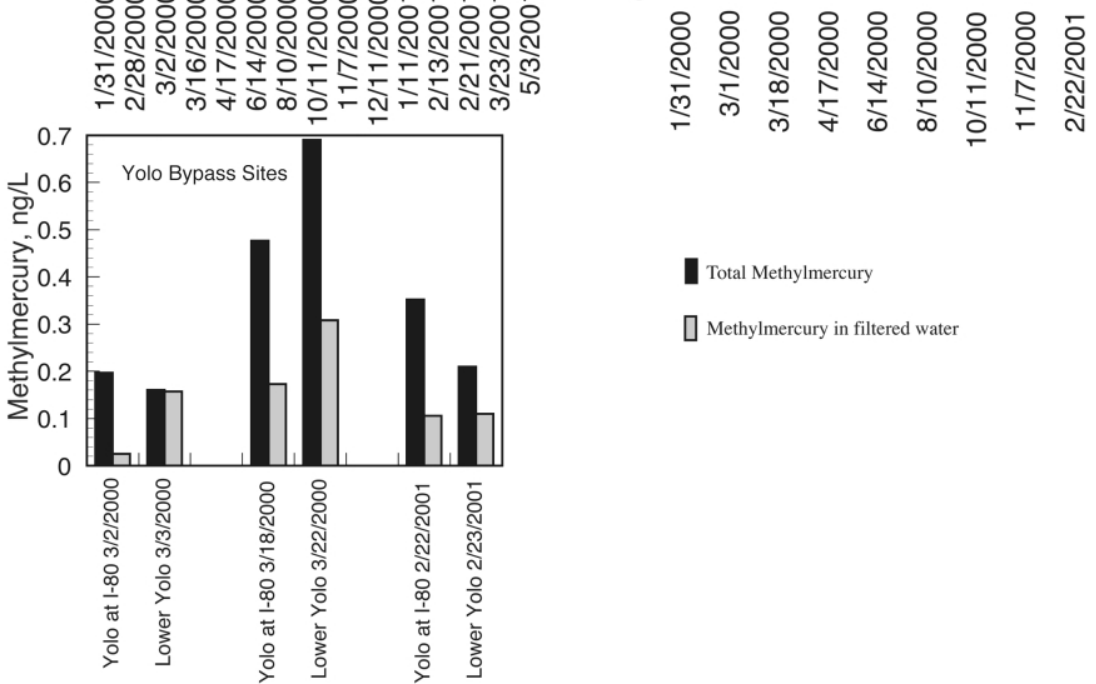

Total Methylmercury

Methylmercury in filtered water

Fig. 4. Methylmercury concentrations at large river sites.

The loads of mercury and methylmercury from the storm of late February and March 2001 were much less than those during the storm of Febru-
ary-March 2000 (Tables 2 and 3). The sum of the loads originating from the mining and geothermal sites, as measured on the storm of February 

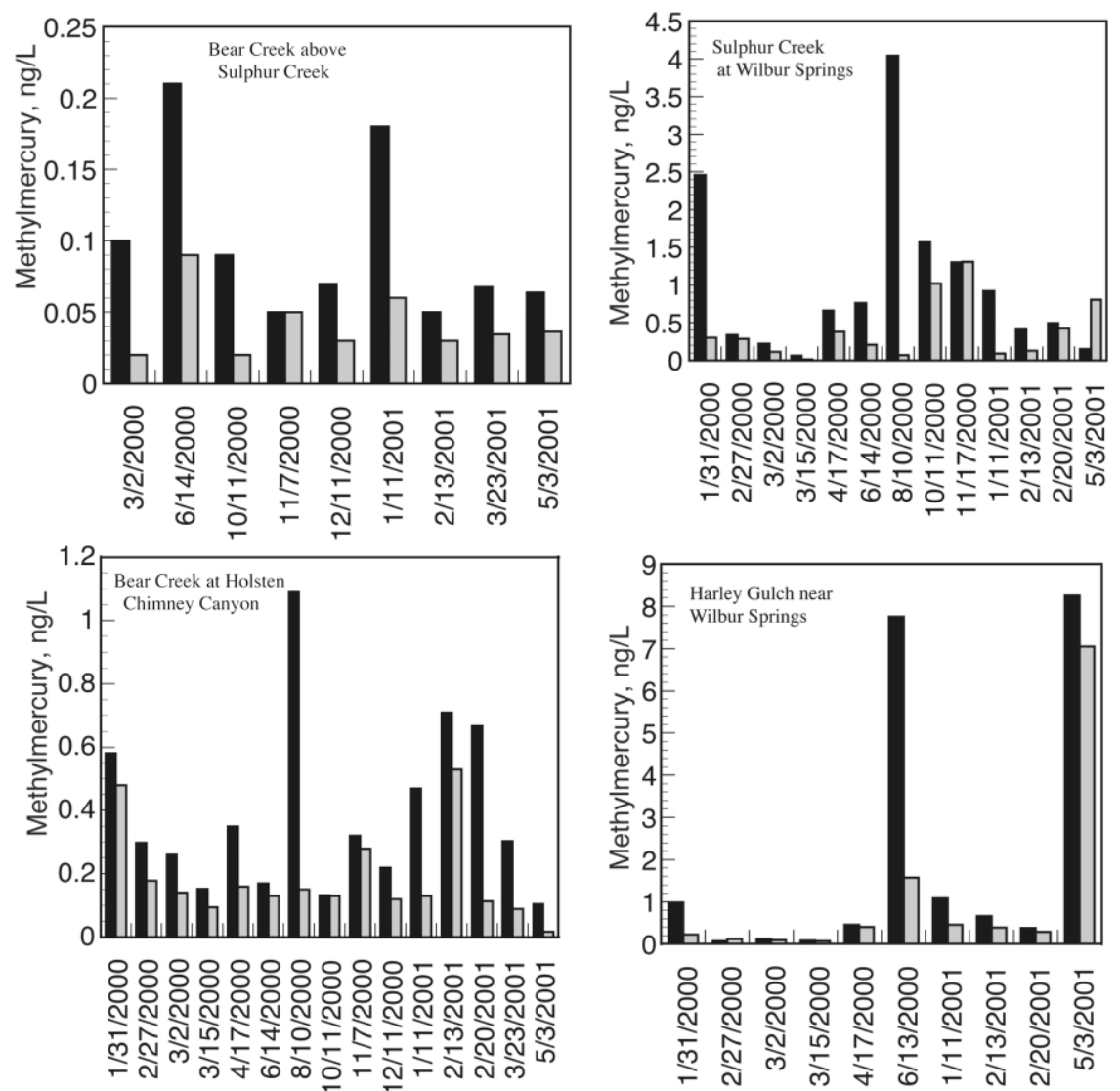

Total Methylmercury in unfiltered water

Methylmercury in filtered water

Fig. 5. Methylmercury concentrations at small stream sites.

2001 was close to that measured at the Cache Creek at Rumsey and downstream. During that storm, there was very low discharge of water from both Clear Lake and Indian Valley Reservoir. As a result, the mercury loads measured downstream at Cache Creek were more representative of the loads from the mining and geothermal sites.

Patterns of instantaneous loads of total methylmercury for individual sites were generally similar to those for total mercury. The upstream loads of total methylmercury during the February-March 2000 sampling were less than the loads at the downstream sites. During the February 2001 sampling, however, the highest load of total methyl- mercury occurred at the Cache Creek at Rumsey site, with two upper-watershed streams, Bear Creek and the North Fork of Cache Creek, contributing most to the load at Rumsey.

It was not possible to calculate accurate annual discharge or annual loads of mercury from all of the sampling sites, or at all times at individual sites. Continuous records of discharge were only available for Sulphur Creek at Wilbur Springs, Bear Creek above Holsten Chimney Canyon, Harley Gulch near Wilbur Springs, outflow from Clear Lake (Cache Creek near Lower Lake), North Fork Cache Creek near Clearlake Oaks (outflow from Indian Valley Reservoir), and the Yolo Bypass. 
Table 2

Mercury mass loadings during two storm events

\begin{tabular}{lrc}
\hline Site name & Hg load (g/day) & Storm $2^{\text {b }}$ \\
\cline { 2 - 3 } & Storm $1^{\text {a }}$ & 0.2 \\
\hline Cache Creek near Lower Lake & 86 & 67 \\
Bear Creek above Holsten Chimney Canyon & 280 & 35 \\
Sulphur Creek at Wilbur Springs & 51 & 0.009 \\
Harley Gulch near Wilbur Springs & 5 & 0.1 \\
North Fork Cache Creek near Clearlake Oaks & 29 & 12 \\
North Fork Cache Creek at Highway 20 & 129 & Not sampled \\
Davis Creek Reservoir at dam, near Knoxville & 5 & 149 \\
Cache Creek at Rumsey & 213 & 134 \\
Cache Creek into Settling Basin & 2386 & 122 \\
Cache Creek out of Settling Basin & 1864 & 119 \\
Yolo Bypass at Interstate 80 Near West Sacramento & 2267 & 128 \\
Lower Yolo Bypass & 1496 & \\
\hline
\end{tabular}

${ }^{a}$ Storm 1, Sampling occurred from 27 February 2000 through 30 March 2000.

${ }^{\mathrm{b}}$ Storm 2, Sampling occurred from 20 February 2001 to 23 February 2001.

Discharge for the input to the Cache Creek Settling Basin (Lower Cache Creek) was estimated from the discharge record of a nearby gauging station.

Annual discharge and percentage of discharge for the entire Cache Creek watershed and Yolo Bypass for water years 2000 and 2001 for the sites with continuous records are given in Tables 4 and 5.

A significant relationship between concentration and discharge is required to calculate an accurate annual load of any constituent in a river with few observations of the concentration of that constituent and a continuous record of discharge. Linear least-squares regression of the data on stream discharge and total mercury concentrations for the mining or geothermal sites and the input to the Cache Creek Settling Basin had generally poor fits ( $r^{2}$ between 0.008 and 0.14 ). The best relation between stream discharge and total mercury was for the Cache Creek into Settling Basin site $\left(r^{2}=\right.$ $0.7)$, but the regression equation had poor predictive value with a positive $y$-intercept. This lack of

Table 3

Methylmercury mass loadings during two storm events

\begin{tabular}{lcc}
\hline Site name & Methylmercury load (g/day) \\
\cline { 2 - 3 } & Storm $1^{\mathrm{a}}$ & Storm $2^{\mathrm{b}}$ \\
\hline Cache Creek near Lower Lake & 0.63 & 0.002 \\
Bear Creek above Holsten Chimney Canyon & 0.43 & 0.3 \\
Sulphur Creek at Wilbur Springs & 0.03 & 0.03 \\
Harley Gulch near Wilbur Springs & 0.001 & 0.00003 \\
North Fork Cache Creek near Clearlake Oaks & 0.16 & Not detected \\
North Fork Cache Creek at Highway 20 & 0.45 & 0.11 \\
Davis Creek Reservoir at Dam, near Knoxville & 0.05 & Not sampled \\
Cache Creek at Rumsey & 0.67 & 1.45 \\
Cache Creek into Setting Basin & 6.7 & 1.12 \\
Cache Creek out of Settling Basin & 5.1 & 0.75 \\
Yolo Bypass at Interstate 80 near West Sacramento & 21.8 & 1.22 \\
Lower Yolo Bypass & 17.7 & 0.73 \\
\hline
\end{tabular}

${ }^{a}$ Storm 1, sampling occurred from 27 February 2000 through 30 March 2000.

${ }^{\mathrm{b}}$ Storm 2, sampling occurred from 20 February 2001 to 23 February 2001. 
Table 4

Annual discharge for selected sites for water year 2000 (1 October through 30 September), and percent of Cache Creek and Yolo Bypass discharge

\begin{tabular}{lccc}
\hline Site & $\begin{array}{l}\text { Annual discharge } \\
\left(\mathrm{m}^{3}\right)\end{array}$ & $\begin{array}{l}\text { Percent of Cache Creek } \\
\text { Watershed discharge }\end{array}$ & $\begin{array}{l}\text { Percent of Yolo } \\
\text { Bypass discharge }\end{array}$ \\
\hline Sulphur Creek & 2784930 & 1 & 0.1 \\
Bear Creek & 33270770 & 12 & 1 \\
Harley Gulch & 395290 & 100 & 0.15 \\
Lower Cache Creek & 268342150 & & 8 \\
\hline
\end{tabular}

Table 5

Annual discharge for water year 2001 (1 October through 30 September), and percent of Cache Creek and Yolo Bypass discharge

\begin{tabular}{lccc}
\hline Site & $\begin{array}{l}\text { Annual discharge } \\
\left(\mathrm{m}^{3}\right)\end{array}$ & $\begin{array}{l}\text { Percent of Cache Creek } \\
\text { Watershed discharge }\end{array}$ & $\begin{array}{l}\text { Percent of Yolo } \\
\text { Bypass discharge }\end{array}$ \\
\hline Sulphur Creek & 1834700 & 2 & $<1$ \\
Bear Creek & 18267000 & 19 & 9 \\
Harley Gulch & 5020 & 0.005 & $<0.01$ \\
Lower Cache Creek & 93931500 & 100 & 45 \\
\hline
\end{tabular}

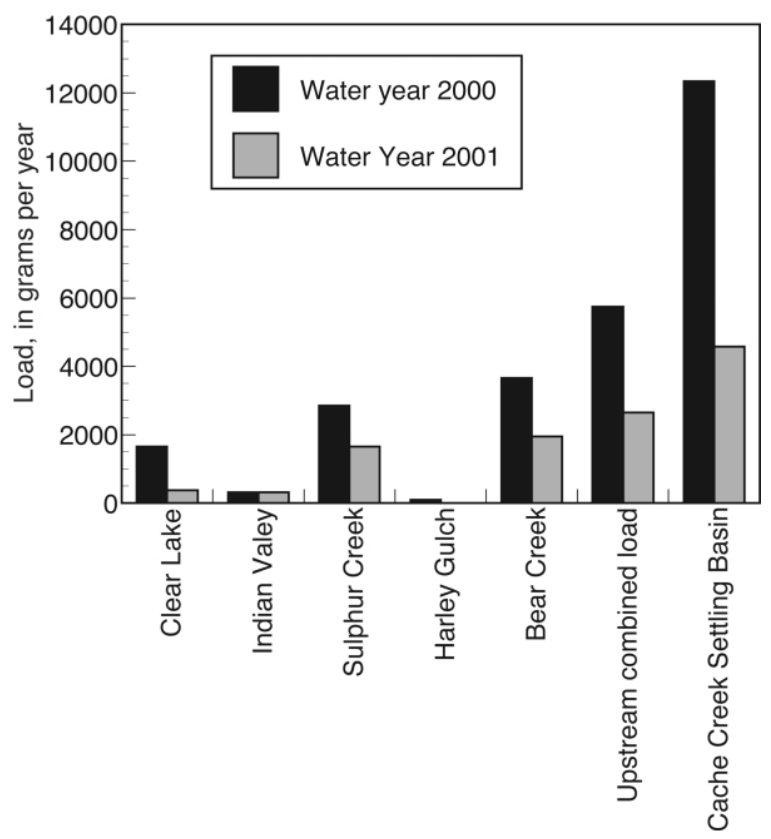

Fig. 6. Annual mercury loads at sites with continuous streamflow records.

a clear relation between discharge and mercury concentration limited our ability to calculate annual loads of mercury for these streams.
A crude estimate of annual mercury loading at select sites may be obtained with an estimated average mercury concentration of the dry season and an average mercury concentration for the wet season, or runoff events, combined with flow data for sites that have reliable records of discharge. For the Clear Lake outflow, a dry-season estimated average of $4 \mathrm{ng} / \mathrm{l}$ of total mercury and a wetseason estimated average of $12 \mathrm{ng} / \mathrm{l}$ of total mercury was used. For the Indian Valley Reservoir, an estimated average of $2 \mathrm{ng} / 1$ of total mercury for the dry season and $5 \mathrm{ng} / \mathrm{l}$ during the wet season were used. For Harley Gulch, an estimated average of $169 \mathrm{ng} / \mathrm{l}$ for the dry season and 279 $\mathrm{ng} / \mathrm{l}$ for the wet season were used. For Bear Creek, similar concentrations of $38 \mathrm{ng} / \mathrm{l}$ and 131 ng/l were used, respectively. For Sulphur Creek, values of 758 and $1095 \mathrm{ng} / 1$ were used. For the Cache Creek Settling Basin, concentrations of 1.3 and $51.3 \mathrm{ng} / 1$ were used.

Annual loads for each year of the study were calculated for sites that have continuous streamflow records. These annual loads are shown in Fig. 6 . For both water years, the loads from Sulphur Creek are greater than those form either Clear Lake or the Indian Valley Reservoir. Loads from Sulphur Creek are also much greater than those 


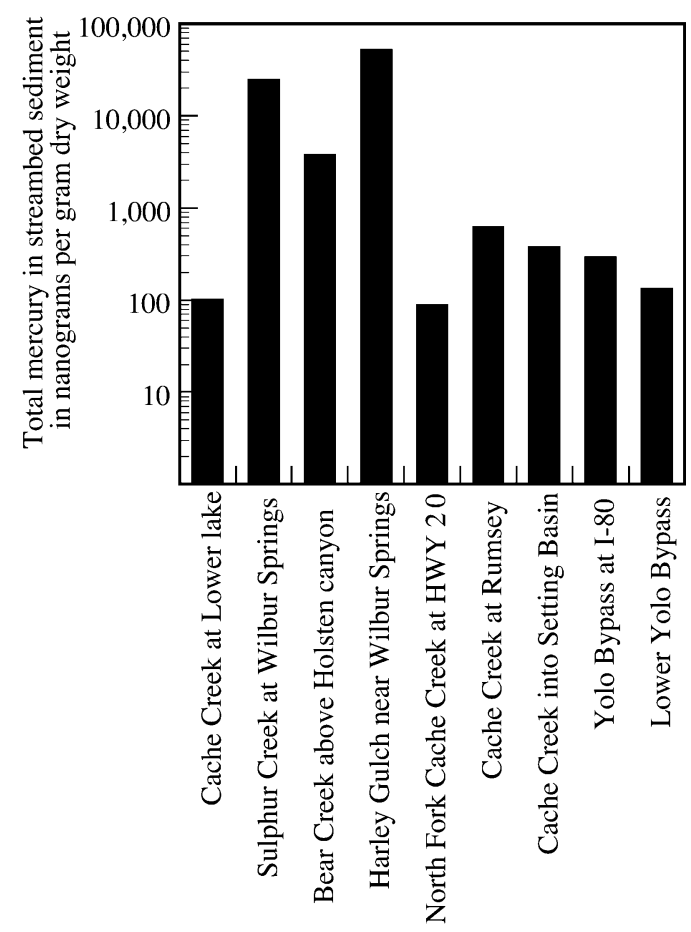

Fig. 7. Total mercury in streambed sediment at selected sites.

from Harley Gulch, which is immediately downstream of a large mercury mine. Because of the lower than normal rainfall amounts, mercury loads from Harley Gulch were relatively low. Mercury loads from Bear Creek increase slightly from those of Sulphur Creek, probably from re-suspension of previously deposited mercury from Sulphur Creek. When the combined loads of the upstream tributaries are summed, the resulting combined load is less than that calculated for the most downstream site, the Cache Creek Settling Basin. This increase in loads between the mine and geothermal sites and the most downstream site can be logically attributed to re-suspension of previously deposited mercury. Erosion of mercury from these mine waste piles has been ongoing for over 100 years. As a result, the bed sediments of Cache Creek are a source of mercury to downstream water bodies.

Concentrations (dry weight) of total mercury in streambed sediments collected during the late fall of 2000 are shown on Fig. 7. As expected, concentrations were considerably higher in the sedi- ments from the mining or geothermal sites relative to the sites downstream on Cache Creek or the North Fork of Cache Creek.

Mercury mining began approximately 150 years ago at locations in the Cache Creek basin, and the wastes from those operations remain a continuing source to downstream locations. Because these sites are impacted by mining activities, there is no way of determining what the concentration of mercury in streambed sediment would be in the absence of mining. Mercury concentrations were $100 \mathrm{ng} / \mathrm{g}$ of dry sediment in streambed sediment taken just below Clear Lake and $87 \mathrm{ng} / \mathrm{g}$ of dry sediment in the North Fork of Cache Creek near Highway 20. It is to be expected that mercury concentrations in sediment from the Cache Creek at Rumsey site would be higher than those at the Clear Lake site because of runoff from geothermal sources and of naturally occurring mercury in upstream soils. Although no 'pre-mining background' concentration of mercury in sediment could be derived for the Cache Creek at Rumsey site, the present concentrations have probably been influenced by human activities for more than 150 years and almost certainly exceed the pre-mining levels. Because of the anthropogenic influences on the Cache Creek at Rumsey site, the streambed sediments along Cache Creek can be considered as an additional source of mercury to downstream areas.

The aqueous chemistry at various locations within the Cache Creek Basin can vary seasonally because of chemical differences among the inflowing waters from different sources. These variations in chemistry, related to water source, may be useful in relating the sources of mercury or methylmercury at downstream locations if the water associated with these mercury sources have distinguishable geochemical signatures. Some potentially useful chemical tracers include the aqueous concentrations of chloride $(\mathrm{Cl})$, sulfate $\left(\mathrm{SO}_{4}\right)$, boron $(\mathrm{B})$, and lithium $(\mathrm{Li})$, the relative amounts of dissolved or suspended mercury, and the stable isotopes of hydrogen and oxygen in water.

An example of a chemical signature for the Cache Creek at Rumsey site is aqueous chloride and sulfate. A 2-year profile of $\mathrm{Cl} / \mathrm{SO}_{4}$ ratios with data from a previous study is shown in Fig. 8 


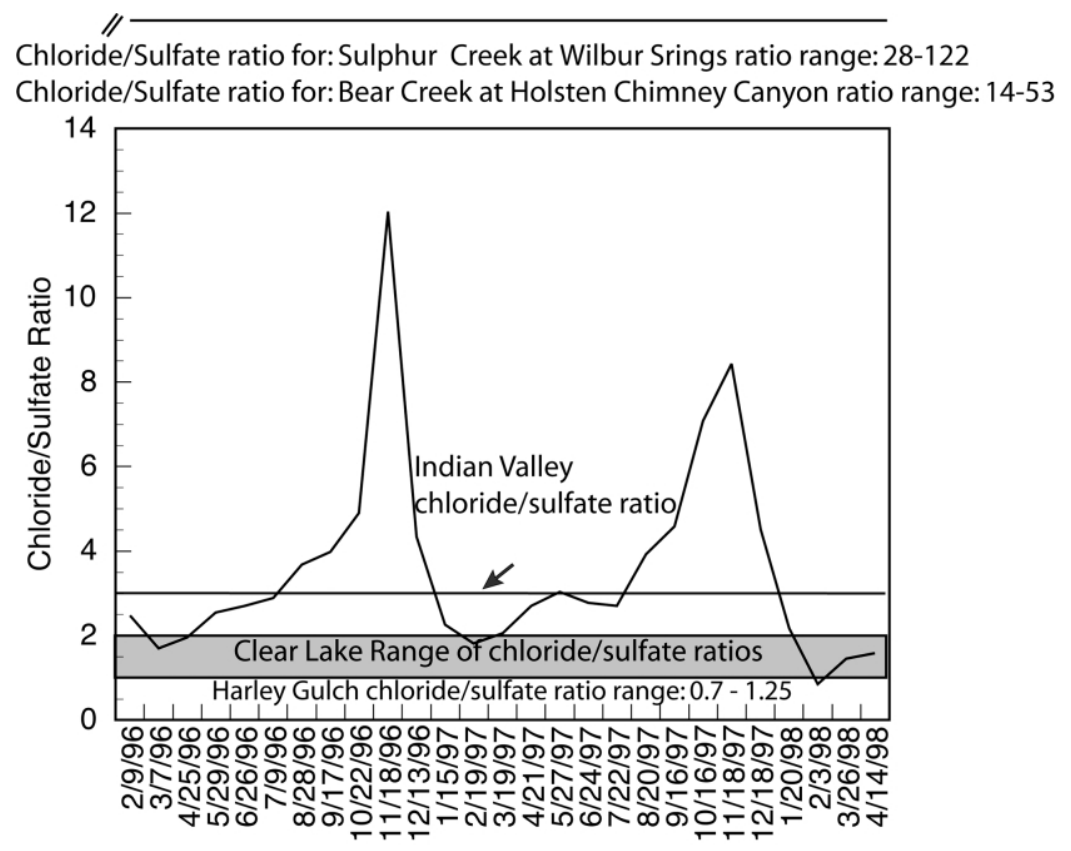

Fig. 8. Ratio of chloride to sulfate at the Cache Creek at Rumsey site and at other selected sites within the Cache Creek basin.

(Domagalski et al., 2000b). Also, shown in that figure are $\mathrm{Cl} / \mathrm{SO}_{4}$ ratios from select sites using data collected during the present study. The $\mathrm{Cl} /$ $\mathrm{SO}_{4}$ ratio is mostly dependant on whether Clear Lake or the Indian Valley Reservoir is the primary source of water (typically during the irrigation season and wet season), or whether Bear and Sulphur creeks dominate the flow (typically during late fall to early winter). Because of the higher chloride content in the geothermal springs within the Sulphur Creek drainage, the $\mathrm{Cl} / \mathrm{SO}_{4}$ ratio increases as the percentage of water from Sulphur Creek increases. The Harley Gulch samples have a low $\mathrm{Cl} / \mathrm{SO}_{4}$ ratio because of their higher concentrations of sulfate derived from the mine waste. As a result of the higher sulfate concentrations, the $\mathrm{Cl} / \mathrm{SO}_{4}$ ratio is relatively low in Harley Gulch water. Winter storm water runoff indicates a mixed source. The water chemistry changes significantly in the fall, with large changes in the $\mathrm{Cl} / \mathrm{SO}_{4}$ ratio. As the irrigation season ends, and flows from Clear Lake and Indian Valley Reservoir are decreased, the percentage of Sulphur Creek and
Bear Creek water in Cache Creek increases, resulting in the large increase in the $\mathrm{Cl} / \mathrm{SO}_{4}$ ratio.

It was hypothesized that systematic changes in the differences in select element ratios in water, from upstream mining and geothermal sources, to downstream locations, might be useful as tracers of which locations (abandoned mines or geothermal springs) are important sources of mercury or methylmercury to downstream locations. Geochemical tracing of mercury transported to downstream areas to specific source areas would provide a powerful tool for mine re-mediation and cleanup efforts. Erosion of geologic material at the mine or geothermal sites, for example, might differ from that of the surrounding geologic material at other locations such that runoff from the mine or geothermal sites would have characteristic signatures with respect to element ratios. An analysis of whole-water samples was completed by computing the ratios of the amounts of various elements in whole water samples to the amount of aluminum. Aluminum has low solubility, but is a major constituent of the rock types found in the Cache 


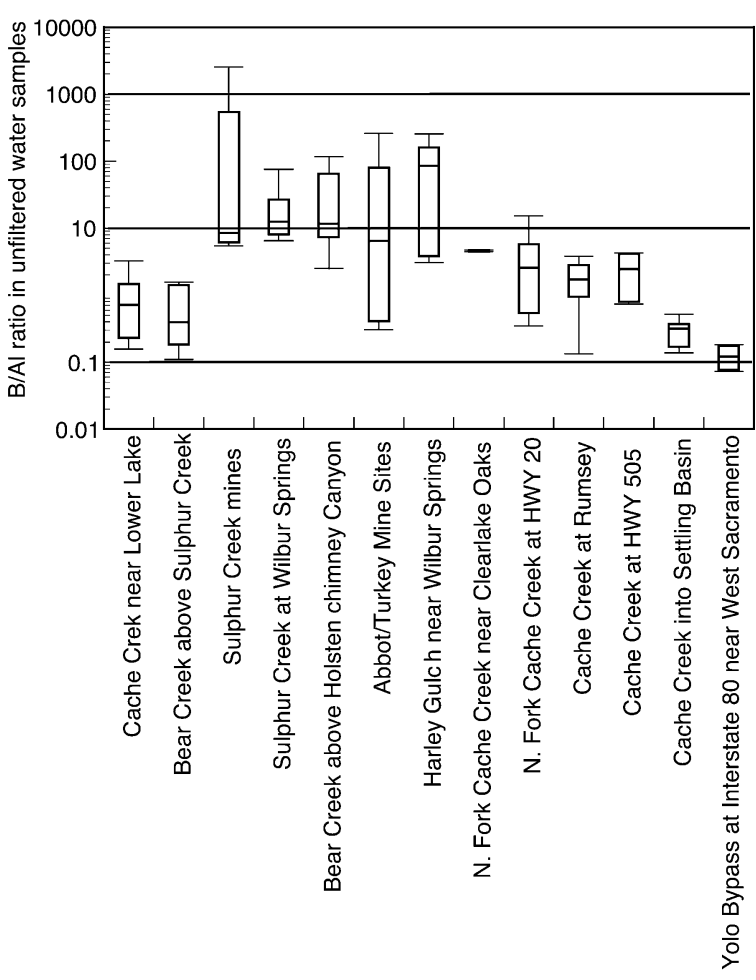

Fig. 9. Boron to aluminum mass ratios at selected sites of the Cache Creek Basin and Yolo Bypass.

Creek basin. Therefore, it was reasoned that normalizing the element concentrations in wholewater samples to that of aluminum might provide useful chemical signatures.

Boron concentrations were found to differ among various locations throughout the Cache Creek Basin. A plot of the ratios of boron to aluminum $(\mathrm{B} / \mathrm{Al})$ for mining and other sites within the Cache Creek Basin is shown in Fig. 9. Many of the mining and geothermal sites, such as those of the Abbott and Turkey Run mines, the Sulphur Creek mines, sites that are downstream of mines, such as Harley Gulch, and sites downstream of geothermal streams, such as Sulphur Creek, generally have higher $\mathrm{B} / \mathrm{Al}$ ratios relative to other non-mining or non-geothermal sites. The outflow from Clear Lake (Cache Creek at Lower Lake) and the Upper Bear Creek (Bear Creek above Sulphur Creek) has relatively low $\mathrm{B} / \mathrm{Al}$ ratios. The median values of the $\mathrm{B} / \mathrm{Al}$ ratio for the outflow from Clear Lake and the Upper Bear Creek did not differ statistically, according to the Mann-Whitney non-parametric test. The upper Bear Creek and the lower Bear Creek (Bear Creek above Holsten Chimney Canyon) sites are different $(P=0.0001)$ by the same statistical test. Water from Sulphur Creek probably has the greatest impact on the $\mathrm{B} / \mathrm{Al}$ ratio at the Bear Creek above Holsten Chimney Canyon site. The B/Al ratio for the Bear Creek above Holsten Chimney Canyon and the Sulphur Creek at Wilbur Springs site are similar and well above that of the Bear Creek above Sulphur Creek site.

The B/Al ratios for Sulphur Creek, the Sulphur Creek mines, Bear Creek above Holsten Chimney Canyon, Harley Gulch near Wilbur Springs, and the Abbott-Turkey mine sites were statistically similar $(P>0.05)$. The $\mathrm{B} / \mathrm{Al}$ ratio of Indian Valley Reservoir was higher than that of Clear Lake and that had an influence on the chemistry of the Cache Creek. Although relatively few water samples were collected at the outlet of Indian Valley Reservoir (North Fork Cache Creek near Clearlake Oaks), the B/Al ratio appeared to be higher than that of Clear Lake, and this higher ratio probably affected the chemistry of the downstream site of Cache Creek at Rumsey. The B/Al ratios were similar at the Cache Creek sites near Highway 505 and Rumsey, but the ratio at the Cache Creek Settling Basin was much lower and similar to that at Clear Lake. Therefore, the mine and geothermal chemical signature of boron to aluminum was distinctive in the upper part of the watershed, but was lost before Cache Creek discharges into the Yolo Bypass.

Although the $\mathrm{B} / \mathrm{Al}$ ratio in water is similar at the geothermal and mining sites, boron and lithium might co-vary, and the concentrations of both boron and lithium might be highest in geothermal water (Goff et al., 1993a,b). A plot of boron and lithium concentrations in water from the study sites is shown in Fig. 10. There is a very good relation between these two elements and the regression coefficient $\left(r^{2}\right)$ for all sites was 0.99 . As expected, the concentrations of boron and lithium were highest in water from the Sulphur Creek at Wilbur Springs and nearby Sulphur Creek mine sites. There was considerable overlap in 


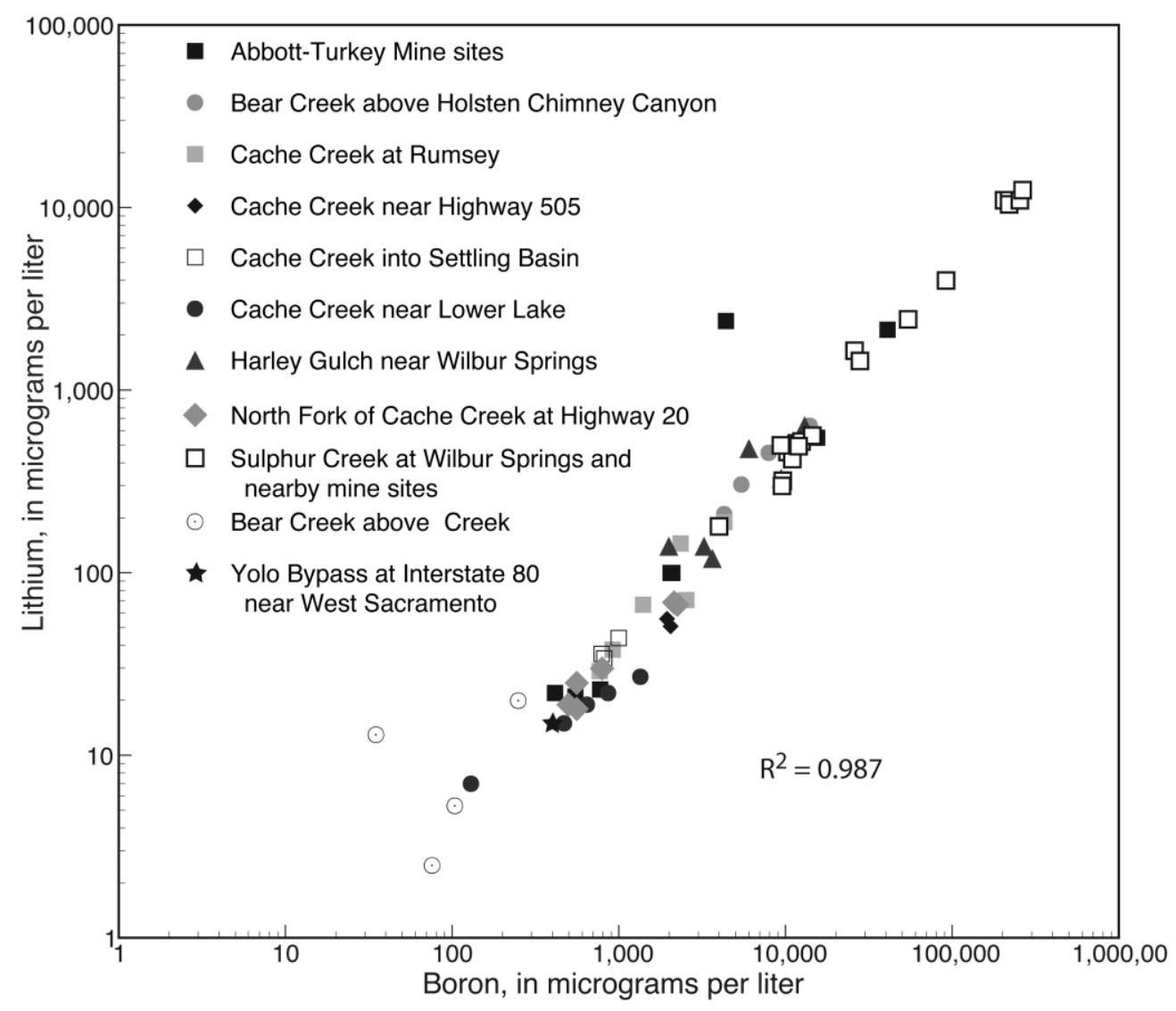

Fig. 10. Plot of boron and lithium concentrations at selected sites within the Cache Creek watershed.

ranges of concentrations between Sulphur Creek and waters from Abbott and Turkey Run Mine and Harley Gulch. Because of the discharge of Sulphur Creek into Bear Creek, the boron and lithium concentrations of Bear Creek above Holsten Chimney Canyon water samples partially overlapped with those of Sulphur Creek or Sulphur Creek mine samples. The boron and lithium concentrations of water from Bear Creek upstream of its confluence with Sulphur Creek, which is above the mining and geothermal influence, were the lowest of all samples. As with the $\mathrm{Cl} / \mathrm{SO}_{4}$ ratio, the concentrations of boron and lithium tend to be low in water from Clear Lake and Indian Valley Reservoir, which partially dilute the concentrations from mine waste or geothermal water in Cache Creek. Boron and lithium were elevated at the
Cache Creek at Rumsey, relative to the concentrations in either Clear Lake outflow or the North Fork of Cache Creek, but it is unclear whether the source is from geothermal or the mine sites. Similar relations were found for boron and chloride (Donnelly-Nolan et al., 1993; Goff et al., 1993a,b).

The relation among boron, chloride and sulfate is also shown with a ternary plot (Fig. 11). In this plot, the relative amounts are shown on a molar basis. A mixing relation of Sulphur Creek water, Bear Creek at Holsten Chimney Canyon, and in some cases, the Cache Creek at Rumsey, and the Cache Creek near Highway 505, is apparent from the plot. The water of the Cache Creek at Rumsey had a similar chemistry to that of Sulphur and Bear Creeks, as seen by the ratio of chloride to sulfate in water, when the outflows from the Indian 


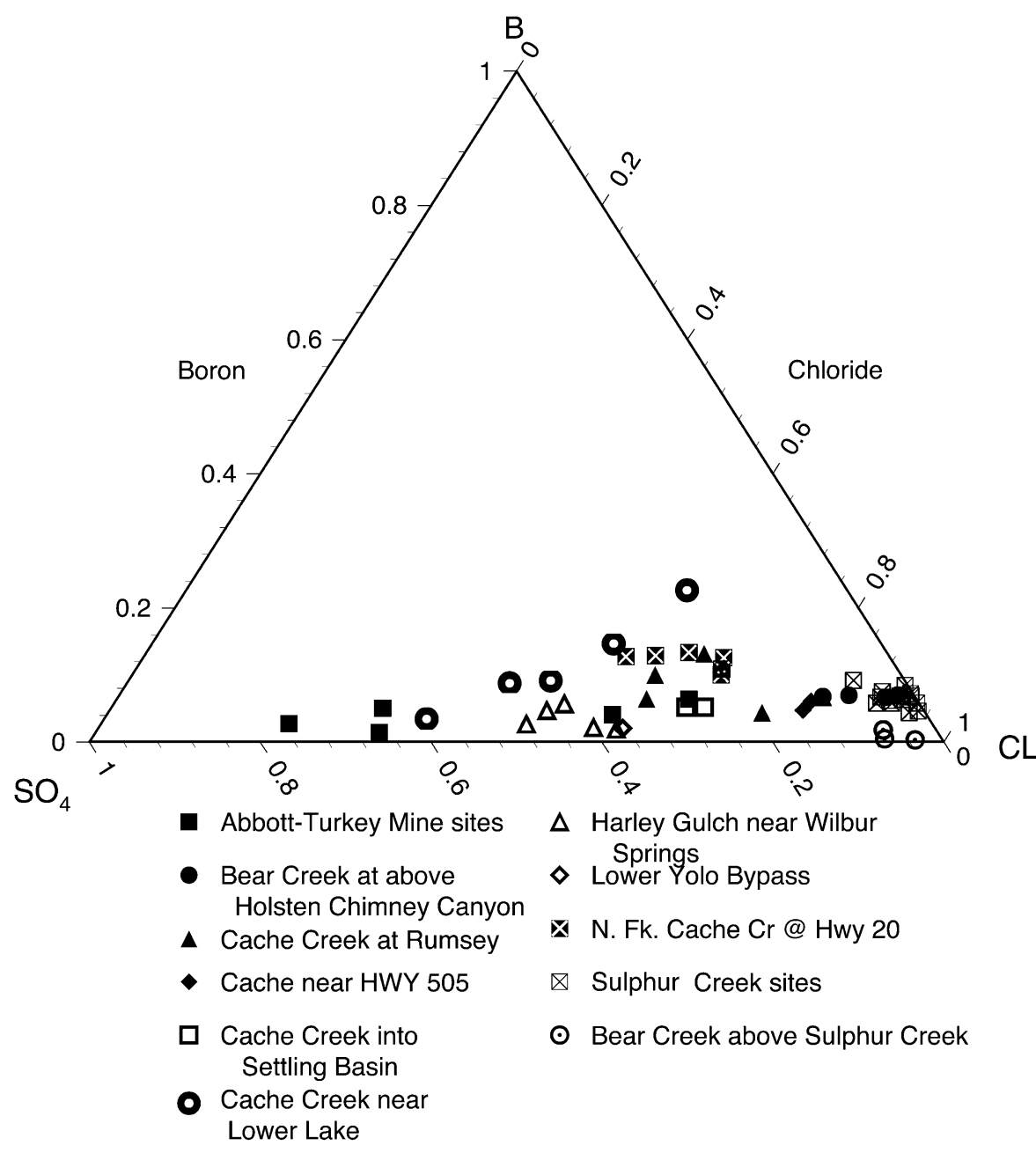

Fig. 11. Ternary plot of boron, chloride and sulfate for selected sites within the Cache Creek watershed.

Valley Reservoir and Clear Lake were low. That happens in the fall, after the irrigation season and before the rainfall/runoff season. At other times of the year, the water of the Cache Creek at Rumsey is more similar to that of either Indian Valley Reservoir, or Clear Lake. The water at Cache Creek had a lower relative amount of boron, or higher chloride and sulfate, relative to that of the Indian Valley Reservoir or Clear Lake. The Abbott-Turkey Run mine and Harley Gulch water samples plot along a range of chloride and sulfate levels. It is not possible to distinguish any mixing trend of the Abbott-Turkey Run Mine and Harley
Gulch waters with downstream sites, such as the Cache Creek at Rumsey.

Another useful signature is the stable isotopic composition of water. Hydrogen and oxygen isotope ratios were measured in samples collected from most of the sites of the present study (Fig. 12). Stable isotope signatures of the geothermal waters have also been previously reported (Goff et al., 1993a,b). Many of the water samples collected during this study had isotopic distributions that plot away from the global meteoric water line, which is based on worldwide stable isotope patterns $\left(\delta^{18} \mathrm{O}\right.$ and $\left.\delta \mathrm{D}\right)$ in rainfall. Stable isotope 


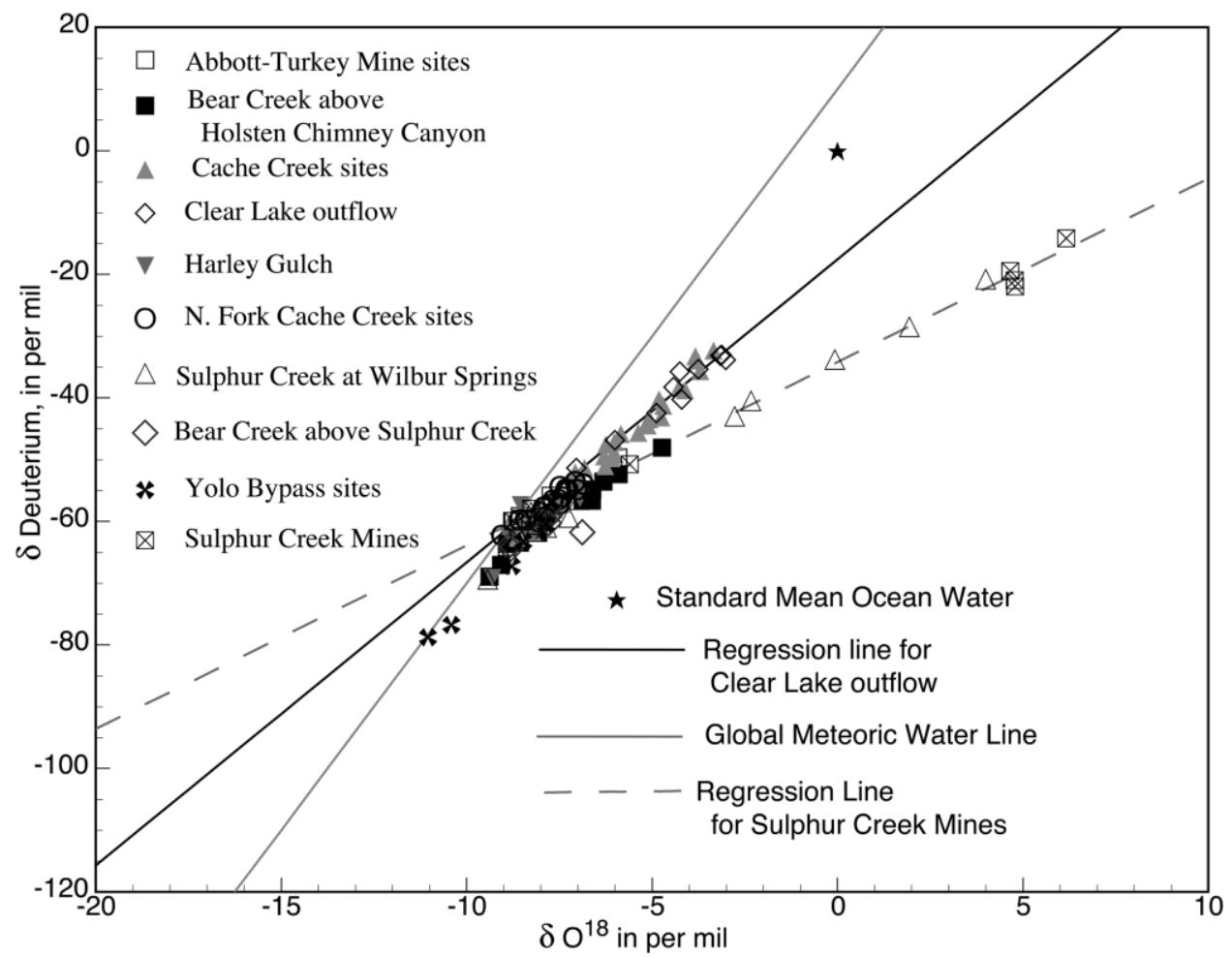

Fig. 12. Plot of stable isotopes ( $\delta$ deuterium and $\delta^{18} \mathrm{O}$ ) for selected sites within the Cache Creek watershed.

ratios of ${ }^{18} \mathrm{O} /{ }^{16} \mathrm{O}$ and ${ }^{2} \mathrm{H} /{ }^{1} \mathrm{H}$ in rain become progressively smaller as air masses leave the ocean and move inland and towards the poles. By definition, ocean water has values of $\delta^{18} \mathrm{O}$ and $\delta \mathrm{D}$ equal to 0.0. Water that plots away from the global meteoric water line usually indicates some type of isotopic fractionation such as may occur during evaporation or certain types of water-rock interactions (Drever, 1982).

The waters from the Sulphur Creek and the Sulphur Creek mines had the greatest deviation from the global meteoric water line. The samples from the Sulphur Creek mine sites were most enriched in ${ }^{18} \mathrm{O}$. The samples from the Bear Creek above Holsten Chimney Canyon plotted along a mixing line from the Sulphur Creek waters. The large deviation from the global meteoric water line was a unique geochemical signature for the waters of this study. In contrast, the waters from the Abbott-Turkey Run mines and those from Harley
Gulch were more depleted in ${ }^{18} \mathrm{O}$ and plotted closer to the global meteoric water line. The runoff from the Abbott-Turkey Run mines and the water in Harley Gulch are generally not affected by geothermal discharge, and therefore their isotopic distribution is more typical of rain.

A second prominent feature of the isotope plot shown in Fig. 12 is the regression line for the Clear Lake outflow. The isotopic signature from that site was similar to those for Cache Creek at Rumsey, Cache Creek near Highway 505, and the Cache Creek Settling Basin. The Clear Lake mixing line is indicative of the isotopic composition of Clear Lake water, which resulted from the longterm evolution of lake water caused by evaporation and local geothermal input over geologic time. The water that is most depleted in the heavier isotopes is that of the Yolo Bypass. That water plots on or just below the global meteoric line. Much of the water in the Bypass was from the 
Sacramento River, which is depleted in the heavier isotopes, and also plots on the global meteoric water line (Domagalski et al., 2001). Therefore, the isotopic patterns of the geothermal waters are very distinct in the small streams in the upper part of the Cache Creek Basin, but the signature of Clear Lake water dominates at locations on Cache Creek downstream of the mining and geothermal sites.

Plots of chemical constituents and stable isotopes of water molecules can be used to show mixing relations and to evaluate whether or not constituent transport is conservative. Plots of lithium vs. $\delta^{18} \mathrm{O}$, and total mercury vs. $\delta^{18} \mathrm{O}$ are shown in Fig. 13, for sites along a flow path from Sulphur Creek through Bear Creek. The water samples from Sulphur Creek with the highest enrichment in the heavier isotope of oxygen were the result of mine drainage or a higher percentage of geothermal discharge into Sulphur Creek. Elevated concentrations of both lithium and mercury in Sulphur Creek water plotted across a range of oxygen isotope signature. Dissolved lithium shows a continuous mixing line from the Sulphur Creek mines to the Sulphur Creek near Wilbur Springs waters, for the samples that are most enriched in ${ }^{18} \mathrm{O}\left(\delta^{18} \mathrm{O}>-2\right)$. In contrast, for mercury, there is no suggestion of a continuous mixing line from the Sulphur Creek mines to the water of Sulphur Creek near Wilbur Springs. Mercury in the mine waters probably sorbs to sediment particles and precipitates to the streambed. Lithium is probably transported more or less conservatively in these waters because it is dissolved, and does not precipitate as a mineral along this flow path or become absorbed to other sediment particles. This non-conservative transport of mercury limits our abilities to trace mercury deposited in downstream areas to source areas using geochemical or isotopic tracers.

\section{Summary and conclusions}

A 17-month study of mercury and methylmercury concentrations and loads was completed in the Cache Creek watershed. Tributaries to Cache Creek located downstream of abandoned mercury mines and in proximity of geothermal discharges were sampled for mercury and methylmercury and other aqueous constituents. Other major tributaries to Cache Creek and Cache Creek itself were also sampled in several locations, as was the Yolo Bypass, which receives water from Cache Creek and the Sacramento River during flood conditions. The study period was one of relatively low stream discharge in this watershed compared with historical records, because of relatively low rainfall. Consequently, observed loads of mercury and methylmercury were probably less than that occur during years of normal or above-normal precipitation. Geothermal springs were the source of the highest loads of mercury during this study. This was attributed to the lower than normal rainfall, which failed to produce large run-off events capable of eroding mine wastes. The largest instantaneous loads of mercury and methylmercury occurred in the winter months in response to rainfall-induced runoff. Loads of mercury and methylmercury were generally low in the summer months because of low stream discharge. Release of water from either Clear Lake or Indian Valley Reservoir, for the purpose of either flood control or to supply irrigation water to downstream farms, may also increase the loads of mercury and methylmercury by re-suspension of previously deposited streambed sediment containing elevated amounts of mercury or methylmercury. Although the loads of mercury and methylmercury can be low during the dry season, concentrations can be elevated at other times of the year. This was particularly true for methylmercury, which tends to have elevated concentrations in April-May, July-August, and January.

Water from the geothermal and mining locations had relatively unique geochemical signatures, especially for stable isotopes of water and other aqueous constituents such as boron, chloride, sulfate and lithium. The ratio of chloride to sulfate in water samples from Cache Creek at Rumsey shows strong seasonal variations that can be attributed to different sources of water in the watershed. The aqueous constituents are also useful as tracers for geothermal sources of water and for evaluation of the extent to which mercury is transported conservatively. Concentrations of lithium, a conservatively transported ion, correlate well with 

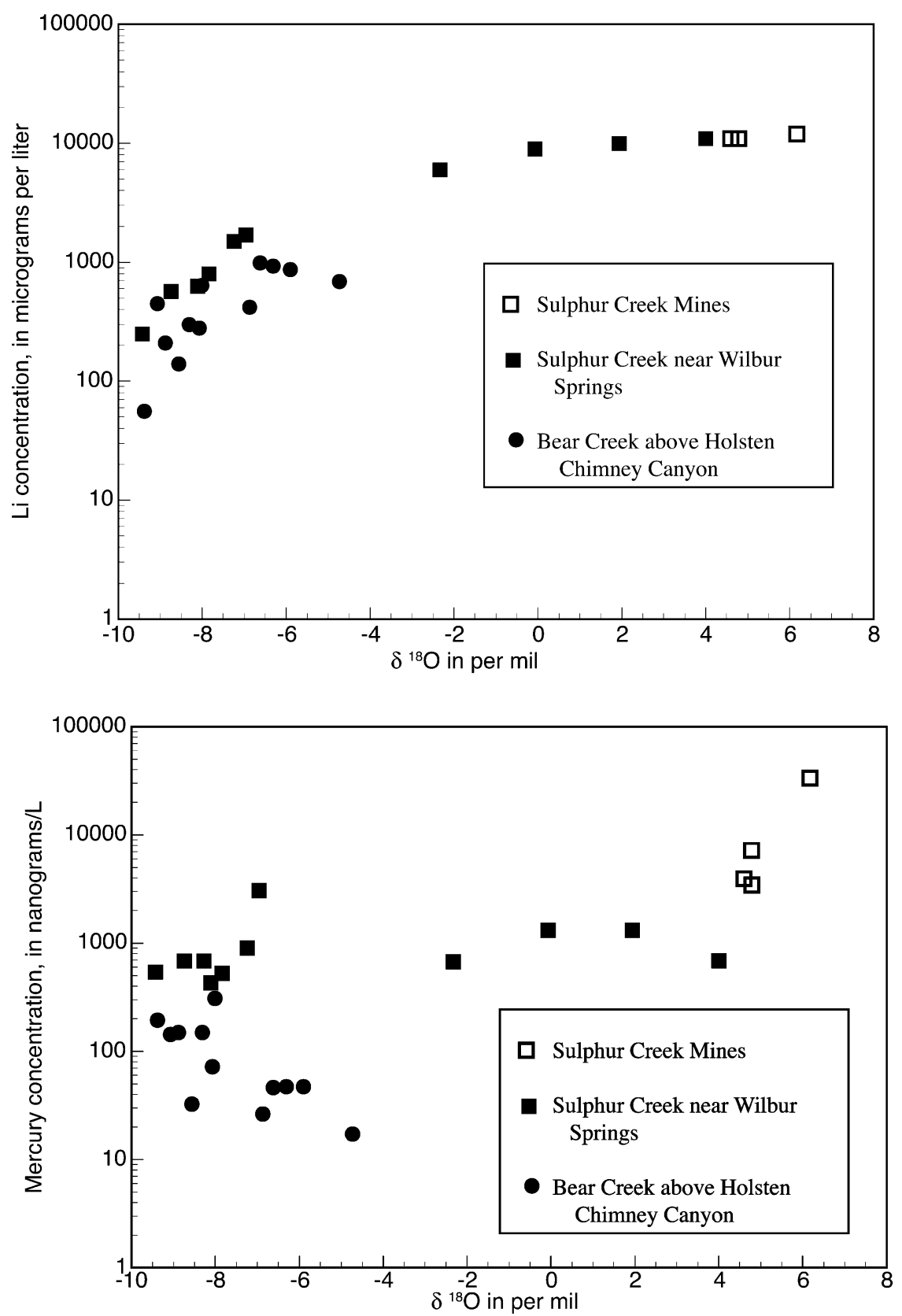

Fig. 13. Plots of lithium and total mercury vs. $\delta^{18} \mathrm{O}$ for selected sites within the Cache Creek watershed.

oxygen isotopes along a mixing and dilution flow path from Sulphur Creek through Bear Creek, indicating that all of these constituents are transported conservatively. In contrast, total mercury does not correlate well with oxygen isotopes or the other aqueous constituents, indicating that mercury transport is non-conservative. It is hypothesized that dissolved mercury from the geothermal 
sources is largely adsorbed onto fine-grained sediments in Sulphur Creek and lower Bear Creek, or further downstream in Cache Creek. Mercury transport in the tributaries dominated by geothermal sources is highly episodic, with much of transport related to the re-suspension of previously deposited sediment. Mercury transport in tributaries dominated by mining sources such as Harley Gulch is also related to sediment transport mechanisms, as the main form of mercury is hypothesized to be particles of mercury sulfide (cinnabar and metacinnabar).

\section{References}

Alpers CN, Taylor HE, Roth DA, Cain DJ, Ball JW, Unruh DM, Dileanis PD. Study design: field and laboratory methods. In: Alpers CN, Taylor HE, Domagalski JL, editors. Metals Transport in the Sacramento River, California, 19961997: US Geological Survey Water-Resources Investigations Report 99-4286, 2000; pp. 19-38.

Anderson SW, Rockwell GL, Smithson JR, Friebel MF, Webster MD. Water Resources Data California Water Year 2000, vol. 4. Northern Central Valley Basins and the Great Basin from Honey Lake Basin to Oregon State Line, Water-Data Report CA-00-4, 2001.

Bigeleisen J, Perlman ML, Prosser HC. Conversion of hydrogenic materials to hydrogen for isotopic analysis. Anal Chem 1952;24:1356-1357.

Bradley EM. Quicksilver resources of the state of California. California State Mining Bureau Bull 1918; 78.

Domagalski JL. Occurrence and transport of total mercury and methyl mercury in the Sacramento River Basin, California. J Geochem Exploration 1998;64:277-291.

Domagalski JL. Mercury and methylmercury in water and sediment of the Sacramento River Basin, California. Appl Geochem 2001;16:1677-1691.

Domagalski JL, Dileanis PD. Water-Quality Assessment of the Sacramento River Basin, California-Water Quality of Fixed Sites, 1996-1998: Water-Resources Investigations Report 00-4247, 2000.

Domagalski JL, Knifong DL, Dileanis PD, Brown LR, May JT, Connor V, Alpers CN. Water Quality in the Sacramento River Basin, California, 1994-1998: US Geological Survey Circular 1215, 2000a.

Domagalski JL, Dileanis PD, Knifong DL, Munday CM, May JT, Dawson BJ, Shelton JL, Alpers CN. Water-Quality Assessment of the Sacramento River Basin, California: Water-Quality, Sediment and Tissue Chemistry, and Biological Data, 1995-1998: US Geological Survey Open-File Report 00-391, 2000b, http://ca.water.usgs.gov/ sac_nawqa/waterindex.html.

Domagalski JL, Zhou X, Lin C, Zhi D, Fan Lan C, Xu K, Lü Y, Luo Y, Liu S, Liu D, Guo Y, Tian Q, Liu J, Yu W,
Shedlock R, Knifong D. Comparative Water-quality Assessment of the Hai He River Basin in the People's Republic of China and Three Similar Basins in the United States: US Geological Survey Professional Paper 1647, 2001.

Donnelly-Nolan JM, Burns MG, Goff FE, Peters EK, Thompson JM. The Geysers-Clear Lake Area, California: thermal waters, mineralization, volcanism, and geothermal potential. Econ Geol 1993;88:301-316.

Drever JI. The Geochemistry of Natural Waters. Englewood Cliffs, New Jersey: Prentice-Hall, Incorporated, 1982.

Edwards TK, Glysson DG. Field Methods for Measurement of Fluvial Sediment: US Geological Survey Open-File Report 86-531, 1988.

Foe CG, Croyle W. Mercury concentrations and loads from the Sacramento River and from Cache Creek to the Sacramento-San Joaquin Delta Estuary: California Regional Water Quality Control Board, Central Valley Region, 1999.

Goff F, Adams AI, Trujillo PE, Counce D, Mansfield J. Geochemistry of thermal/mineral waters in the Clear Lake Region, California, and implications for hot dry rock geothermal development. LA-12510 HDR, UC-251, Los Alamos, New Mexico: Los Alamos national laboratory, 1993a.

Goff F, Kenney BM, Adams AI, Trujillo PE, Counce D. Hydrogeochemical evaluation of conventional and hot dry rock geothermal resource potential in the Clear Lake Region, California, Geothermal Resources Council Transactions, vol. 17, 1993b.

Kendall C, Coplen TB. Multisample conversion of water to hydrogen by zinc for stable isotopic determination. Anal Chem 1985;57:1437-1440.

O'Neil JR. Theoretical and experimental aspects of isotopic fractionation. In: Valley JW, Taylor HP, O’Neil JR, editors. Stable Isotopes in High Temperature Geological Processes. Reviews in Mineralogy, 1986; 16: pp. 1-40.

Puckett HM, van Buuren BH. Quality assurance project plan for the CALFED Project: an assessment of ecological and human health impacts of mercury in the Bay-Delta watershed. Monterey, CA: California Department of Fish and Game, 2000.

Roth DA. Ultratrace analysis of mercury and its distribution in some waters of the United States. Ph.D. Dissertation, Colorado State University, Fort Collins, Colorado, 1994.

Rytuba JJ. Cenozoic metallogeny of California. In: Coyner AR, Fahey, PL editors. Geology and Ore Deposits of the American Cordillera. Geological Society of Nevada Symposium Proceedings, Reno/Sparks, Nevada, April 1995, 1996; pp. 803-822.

Shelton LR. Field guide for collecting and processing streamwater samples for the National Water-Quality Assessment Program, US Geological Survey Open-File Report 94-455, 1994.

Suchanek TH, Slotton DG, Nelson D, Ayers SM, Asher C, Weyand R, Liston A, Eagles-Smith C. Mercury Loading and Source Bioavailability from the Upper Cache Creek Mining Districts: CALFED—Cache Creek Study (Task 5A: final Report), 2002, http://loer.tamug.tamu.edu/calfed/ FinalReports.htm, accessed 3 December 2003. 
US Environmental Protection Agency. Method 1631: Mercury in Water by Oxidation, Purge and Trap, and Cold Vapor Atomic Fluorescence Spectrometry. US Environmental Protection Agency, Office of Water, Draft, 821-R-96-012, 1996.

US Geological Survey. National Field Manual for the Collection of Water-Quality Data, Chapter A4. Collection of Water samples, Techniques of Water-Resources Investigations,
Book 9, Handbooks for Water-Resources Investigations, 1999.

Ward JR, Hair CA. Methods for Collection and Processing of Surface-water and Bed-material Samples for Physical and Chemical Analyses: US Geological Survey Open-File Report 90-140, 1990. 